\title{
Penerapan Metode Analytic Network Process (ANP) untuk Mengatasi Keterlambatan Pengadaan Barang pada Bagian Umum di PT Solo Grafika Utama
}

\author{
Aris Wahyu Nugroho ${ }^{1)}$, Rizqy Widhianggitasari ${ }^{2)}$, David Fu'ani Priadi ${ }^{3)}$, Pringgo Widyo \\ Laksono $^{4)}$ \\ ${ }^{123)}$ Mahasiswa Program Studi Teknik Industri, Fakultas Teknik, Universitas Sebelas Maret \\ ${ }^{4)}$ Dosen Program Studi Teknik Industri, Universitas Sebelas Maret \\ J1. Ir. Sutami No 36A, Surakarta 57126
}

\begin{abstract}
Procurement activities of raw materials is one of the vital activity for the company. PT Solo Grafika Utama is one of the companies that rely heavily on this procurement activity for a smooth production. Until now PT Solo Grafika Utama has been working with several suppliers in the procurement of raw materials production. However, in practice, these activities often experience problems such late delivery by suppliers for various things. As a result of delays in the procurement materials makes the production process is hampered or delayed, so the time that required for production process exceeded the production schedule planning that has been set before. This resulted in the delivery of products to consumers experienced delays and it makes them are not satisfied with the performance of the company. Therefore we need an analysis to determine the factors that cause the delay. Once the cause is known, we need a follow-up analysis in order for the supplier selection decision making process of PT Solo Grafika Utama using ANP method. Supplier selection decision-making process of the raw materials in PT. Solo Grafika Utama involves many criteria and sub-criteria assessment which is then compared and processed to obtain the supplier with the highest value and become preferred suppliers for the company.
\end{abstract}

Keywords: Logistics, Supplier, Analytic Network Proccess, Procurement

\section{Pendahuluan}

Pengertian procurement atau pengadaan menurut Sutedi (2012) yaitu mencakup penjelasan dari dari seluruh proses sejak awal perencanaan, persiapan, perizinan, penentuan pemenang lelang hingga tahap pelaksanaan dan proses administrasi dalam pengadaan barang, pekerjaan atau jasa. Dengan kata lain procurement atau pengadaan adalah proses mendapatkan barang dan jasa dengan kualitas yang baik, kuantitas yang sesuai dengan pesanan, pengiriman yang tepat waktu, pengeluaran yang minimum untuk menghasilkan keuntungan atau kegunaan bagi pemerintah, perusahaan, ataupun pribadi melalui sebuah kontrak. Maka procurement merupakan bagian yang penting bagi sebuah perusahaan untuk mempertahankan kelangsungan hidup perusahaan.

Pada Bagian Umum PT. Solo Grafika Utama bekerja sama dengan beberapa supplier untuk mendapatkan barang dan jasa yang diperlukan untuk memperlancar kegiatan proses produksi di perusahaan tersebut. Bahan baku pada PT. Solo Grafika Utama yaitu kertas, supplier yang menyediakan kebutuhan kertas perusahaan yaitu PT. Adhi Prima yang berlokasi di Surabaya dan CV. Abadi jaya. Bagian umum sangat relevan karena persentase biaya-biaya material tinggi, sekitar $\pm 50 \%$ dari ongkos sebuah produk akhir. Hal tersebut menunjukkan bahwa efisiensi di bagian umum bisa memberikan kontribusi yang cukup berarti bagi peningkatan keuntungan (profit) sebuah perusahaan. Bagian Umum memiliki beberapa proses dalam melakukan pengadaan barang. Proses ini secara tidak langsung merupakan suatu langkah awal dalam menjamin kelancaran kelangsungan operasional pabrik. Proses tersebut yang digunakan dengan PO atau Purchace Order.

*Correspondance: ariswahyu.n@gmail.com 
Analisis perlu dilakukan untuk mengetahui penyebab yang mempengaruhi keterlambatan tersebut karena Bagian Umum dituntut untuk bisa menciptakan keunggulan dari segi waktu. Keunggulan dari segi waktu tersebut bisa dilakukan Bagian Umum dengan memilih supplier yang memiliki kemampuan untuk mengirim barang dalam waktu yang lebih pendek tanpa harus mengorbankan kualitas dan meningkatkan harga. Kecepatan dan ketepatan waktu pengiriman dari supplier bukan hanya memungkinkan perusahaan untuk memproduksi dan mengirim produk ke pelanggan secara tepat waktu, namun juga bisa mengurangi tingkat persediaan bahan baku atau komponen yang harus disimpan sehingga juga akan berakibat pada penghematan biaya. Berdasarkan latar belakang tersebut, maka dirumuskan permasalahan dari penelitian ini, antara lain apa yang menjadi penyebab keterlambatan pengadaan barang, pengaruh apa yang dapat ditimbulkan dari keterlambatan pengadaan barang dan bagaimana solusi untuk mengatasi masalah keterlambatan pengadaan barang tersebut.

Untuk mengetahui penyebab keterlambatan pengadaan barang digunakan diagram tulang ikan sebagai alat pengidentifikasi masalah. Diagram sebab-akibat dikembangkan oleh Dr. Kaora Ishikawa pada tahun 1943, sehingga sering disebut dengan diagram ishikawa. Diagram sebabakibat menggambarkan garis dan simbol-simbol yang menunjukkan hubungan antara akibat dan penyebab suatu masalah (Mardiansyah \& Ikhwana, 2014). Metode ANP (Analytic Network Process) digunakan untuk mengetahui pengaruh yang dapat ditimbulkan dari keterlambatan pengadaan barang dan solusi untuk mengatasi masalah keterlambatan pengadaan barang tersebut. Menurut Saaty (Yulianti, 2013) dari kesederhanaan metodenya membuat ANP menjadi metode yang lebih umum dan lebih mudah diaplikasikan untuk studi kualitatif yang beragam, seperti pengambilan keputusan, peramalan (forecasting), evaluasi, pemetaan (mapping), strategizing, alokasi sumber daya, dan sebagainya.

\section{Tinjauan Pustaka}

Tinjuan pustaka yang digunakan sebagai dasar penelitian, yaitu :

a. Pengadaan (Procurement)

Pengadaan (procurement) barang dan jasa pada suatu instansi atau perusahaan merupakan kegiatan rutin yang selalu dilakukan. Pengadaan barang dan jasa dimaksudkan untuk memenuhi kebutuhan barang dan serta jasa yang diperlukan guna keberlangsungan operasional instansi atau perusahaan.

Banyak perusahaan yang menganggap bahwa pengadaan ini dianggap tidak begitu penting padahal proses ini sangat berarti bagi perusahaan tersebut. Pada beberapa perusahaan pengawasan terhadap pengadaan umumnya tidak dilakukan oleh sumber daya manusia yang bisa diandalkan sehingga perusahaan tersebut tiba-tiba menyadari bahwa pengadaan yang dilakukan menjadi besar. Dengan pengadaan yang semakin besar tersebut maka kinerja suatu perusahaan akan terpengaruh pada kinerja perusahaan penunjang atau terpengaruh pada penyediaan barang atau jasa. Dengan banyaknya pembengkakan pengadaan pada beberapa perusahaan tersebut maka banyak perusahaan yang mengalami kerugian. Kerugian tersebut bila dibiarkan secara terus menerus maka akan mempengaruhi posisi perusahaan. Pembengkakan dalam proses pengadaan tersebut akan menimbulkan penurunan kinerja pengadaan barang ataupun jasa dalam perusahaan sehingga organisasi juga akan terpengaruh. Karena proses pengadaan pabrik yang terlalu lama kadang menjadi masalah pada perusahaan tersebut.

\section{b. Lead Time}

Lead time adalah jangka waktu antara pesanan pelanggan dan pengiriman produk akhir. Perintah yang sedikit dari item yang sudah ada sebelumnya mungkin hanya memiliki lead time beberapa jam, tetapi perintah yang lebih besar dari bagian-bagian custom-made mungkin memiliki lead time minggu, bulan atau bahkan lebih lama. Itu semua tergantung pada sejumlah faktor, dari waktu yang dibutuhkan untuk menciptakan mesin dengan kecepatan sistem pengiriman. Lead time dapat berubah menurut musim atau hari libur atau permintaan keseluruhan untuk produk. Lead time berhubungan dalam manajemen perusahaan, di mana perusahaan ingin mengurangi jumlah waktu yang dibutuhkan untuk memberikan hasil pekerjaan yang baik. Dalam bisnis, minimisasi lead time biasanya lebih difokuskan. 
c. Metode Diagram Tulang Ikan

Diagram tulang ikan adalah alat untuk mengidentifikasi berbagai sebab potensial dari suatu masalah dan menganalisis masalah tersebut. Diagram tulang ikan merupakan suatu alat visual untuk mengidentifikasi, mengeksplorasi dan secara grafik menggambarkan secara detail semua penyebab yang berhubungan dengan suatu permasalahan. Masalah akan dipecah menjadi sejumlah kategori yang berkaitan, mencakup manusia, material, mesin, metode, dan lingkungan. Dengan menggunakan diagram tulang ikan dapat menyelesaikan masalah sampai akarnya.

\section{Metode Penelitian}

Penelitian ini dilakukan dengan menggunakan metode ANP (Analytic Network Process). Metode ANP (Analytic Network Process) merupakan metode yang tepat dalam mengatasi permasalahan ini. Bila dilihat dari permasalahan yang ada, terdapat keterkaitan antara kriteriakriteria dalam pengambilan keputusan pemilihan supplier. Oleh karena itu, dengan menggunakan metode ANP akan diidentifikasi keterkaitan antarkriteria dan dihasilkan keputusan yang terbaik. Kriteria untuk pemilihan supplier adalah biaya, distribusi bahan baku, fasilitas supplier dan karakteristik bahan baku. Setiap kriteria mempunyai beberapa subkriteria yang saling terkait satu sama lain. Berdasarkan identifikasi kriteria/subkriteria serta keterkaitannya, dibangunlah sebuah model keterkaitan Analytic Network Process. Setelah itu seluruh kriteria beserta subkriteria akan dibandingkan satu sama lain. Nilai-nilai perbandingan ini akan diolah dan pada akhirnya didapatkan nilai untuk setiap supplier.

\section{Hasil dan Pembahasan}

\section{a. Penyebab Keterlambatan Pengadaan Barang}

Dari pengamatan lapangan dan wawancara dengan beberapa pihak, penyebab terjadinya keterlambatan pengadaan dapat digambarkan sebagai berikut:

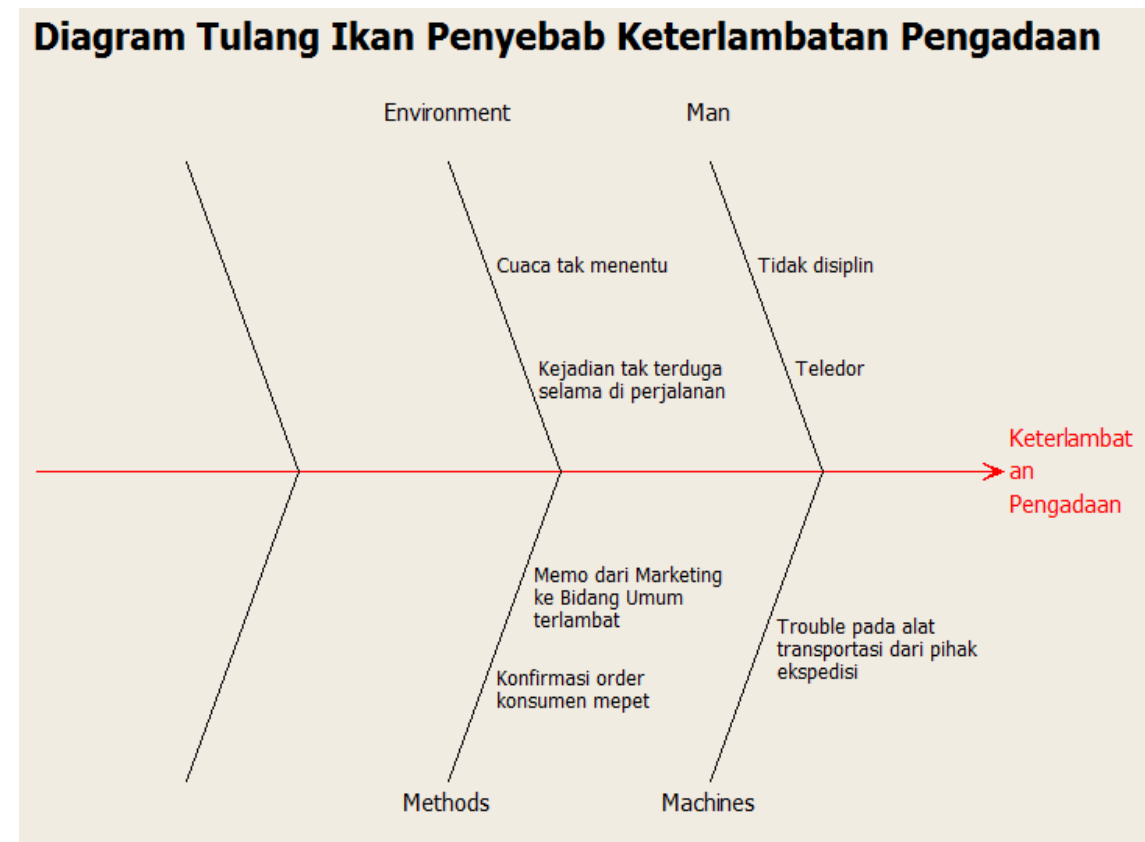

Gambar 1. Diagram Tulang Ikan Penyebab Keterlambatan Pengadaan

Penyebab terjadinya keterlambatan pengadaan dibagi menjadi lima faktor. Faktor-faktor penyebab terjadinya keterlambatan, yaitu :

1) Man (Manusia)

Dari segi manusia, penyebab keterlambatan pengadaan yaitu ketidakdisiplinan dan keteledoran pegawai dalam menjalankan tugasnya. Karena kesalahan pegawai tersebut, maka beberapa pekerjaan harus diulang dan menghambat pekerjaan selanjutnya. Sehingga menyebabkan proses pengadaan terhambat dan mengalami keterlambatan. 


\section{2) Machines (Mesin)}

Yang dimaksud mesin pada penyebab ini adalah alat transportasi yang digunakan. Dari segi mesin, penyebab keterlambatan pengadaan yaitu alat transportasi yang digunakan pihak ekspedisi mengalami gangguan. Gangguan tersebut seperti, truk mogok di jalan, ban truk mengalami bocor, dan lain-lain.

\section{3) Methods (Proses)}

Dari segi metode, penyebab keterlambatan pengadaan paling dominan yaitu konfirmasi order dari konsumen yang mepet. Jika order dari konsumen datang mepet maka pihak perusahaan juga memesan bahan baku secara mendadak. Karena pemesanan bahan baku yang mendadak, terkadang kuantitas yang dikirim tidak sesuai yang dipesan, atau pengiriman bahan baku terlambat disebabkan supplier tidak memiliki stock. Selain itu yang menjadi penyebab keterlambatan pengadaan adalah memo yang diberikan dari Marketing ke Bidang Umum terlambat. Dengan terhambatnya proses aliran informasi antarbidang menyebabkan pemesanan bahan baku mengalami keterlambatan.

4) Environment (Lingkungan)

Dari segi lingkungan, penyebab keterlambatan pengadaan tidak dapat diprediksi. Hal tersebut seperti perubahan cuaca yang tak menentu. Selain itu, kejadian tak terduga selama di jalan juga dapat menyebabkan keterlambatan dalam pengiriman, seperti gempa bumi, kecelakaan, dan lain-lain.

\section{b. Pengaruh Keterlambatan Pengadaan Barang}

Keterlambatan pengadaan barang memberikan dampak negatif pada perusahaan. Dampak yang pertama yaitu proses produksi terhambat sehingga harus ditunda hingga bahan baku datang. Karena proses produksi terhambat atau ditunda, maka pengerjaan produk melebihi jadwal produksi yang telah ditetapkan di awal. Karena penyelesaian produk jadi yang melebihi target waktu yang ditentukan maka pengiriman produk ke konsumen pun juga akan mengalami keterlambatan. Akibat dari pengiriman produk ke konsumen yang terlambat yaitu konsumen tidak puas dengan kinerja perusahaan dan beralih ke perusahaan yang lain.

\section{c. Solusi Mengatasi Masalah Keterlambatan Pengadaan Barang}

Solusi yang digunakan untuk mengatasi masalah keterlambatan pengadaan barang adalah dengan cara menerapkan metode ANP (Analytic Network Process). Pada awal penggunaan metode ANP, perlu didefinisikan kriteria-kriteria yang akan digunakan dalam pengambilan keputusan. Setiap kriteria ini dapat dibagi lagi ke dalam sub-subkriteria apabila diperlukan. Kriteria-kriteria dalam pengambilan keputusan didapatkan dari pihak PT Solo Grafika Utama yang dalam hal ini berwenang menentukan supplier kertas yang akan digunakan. Melalui diskusi yang dilakukan dengan pihak PT Solo Grafika Utama, didapatkanlah kriteria-kriteria pengambilan keputusan yang meliputi kriteria biaya, kriteria distribusi bahan baku, kriteria fasilitas supplier dan kriteria karakteristik bahan baku. Setiap kriteria ini dapat dibagi lagi ke dalam sub-subkriteria yang lebih spesifik.

Kriteria biaya mempunyai subkriteria harga dan potongan harga. Subkriteria harga muncul karena pihak PT Solo Grafika Utama menyadari bahwa harga bahan baku merupakan salah satu hal yang harus diperhatikan. PT Solo Grafika Utama akan berusaha memilih supplier yang menawarkan harga bahan baku lebih rendah sehingga sesuai dengan dana yang dimiliki dan memberikan keuntungan lebih bagi perusahaan. Subkriteria potongan harga pun tentunya muncul karena hal inilah yang akan mempengaruhi harga akhir pembelian bahan baku. Pada kenyataannya, terdapat supplier yang terkadang memberikan potongan harga pembelian bahan baku karena suatu alasan. Tentunya pihak PT Solo Grafika Utama akan memilih suppliersupplier yang demikian untuk mengurangi biaya total pembelian.

Kriteria kedua adalah distribusi bahan baku. Kriteria ini mempunyai subkriteria frekuensi ketepatan waktu pengiriman dan frekuensi pemenuhan pesanan. Frekuensi ketepatan waktu pengiriman berkaitan dengan kemampuan supplier dalam menepati waktu pengiriman yang telah dijanjikan. Dari pengalaman yang dimiliki pihak PT Solo Grafika Utama, keterlambatan kedatangan bahan baku akan berdampak buruk bagi perusahaan. Pemenuhan pesanan kertas 
sering kali tidak sesuai dengan waktu yang diinginkan, namun berat total kertas tetap sesuai dengan pesanan. Hal ini memang sering dimaklumi oleh pihak perusahaan karena mepetnya waktu pesanan dan rintangan transportasi. Namun demikian perusahaan harus memperisapkan back-up supplier apabila hal ini terjadi. Hal ini akan menyebabkan terhambatnya proses produksi sehingga pemenuhan permintaan konsumen menjadi tidak tepat waktu. Oleh sebab itu, diharapkan supplier yang dipilih mampu mengirimkan barang atau pesanan sesuai dengan waktu yang telah disepakati. Subkriteria kedua adalah frekuensi pemenuhan pesanan. Hal ini berkaitan dengan kemampuan supplier dalam memenuhi jumlah pesanan yang diminta pihak PT Solo Grafika Utama. Perusahaan tentunya berharap supplier dapat selalu memenuhi pesanan sesuai dengan jumlah yang diminta.

Kriteria fasilitas supplier berhubungan dengan pelayanan yang diberikan supplier kepada pembeli. Subkriteria dalam kriteria fasilitas supplier ini meliputi cara pembayaran, fleksibilitas, kepercayaan, dan keterbukaan terhadap keluhan. Subkriteria cara pembayaran berkaitan dengan kemudahan pembayaran yang diberikan supplier kepada perusahaan. Hal seperti inilah yang dapat dimanfaatkan perusahaan ketika perusahaan mengalami kekurangan dana dalam pembelian bahan baku. Subkriteria kedua adalah fleksibilitas. Fleksibilitas berkaitan dengan kemudahan dalam mengubah jumlah ataupun jenis pesanan bahan baku. Hal ini memang dimungkinkan bagi supplier-supplier tertentu sehingga menjadi salah satu keunggulan yang harus dipertimbangkan. Subkriteria ketiga adalah kepercayaan. Keputusan dalam memilih supplier tentunya dipengaruhi juga oleh perbandingan rasa percaya terhadap supplier yang ada. Keterbukaan terhadap keluhan merupakan subkriteria yang juga perlu diperhatikan dalam proses pemilihan supplier. Salah satu contoh keluhan yang mungkin adalah kualitas produk yang kurang baik. Apabila supplier sangat tertutup sehingga tidak mau menerima keluhan, tentu akan sangat merugikan PT Solo Grafika Utama sendiri sebagai konsumen karena mendapatkan barang atau produk yang tidak sesuai dengan kriteria yang diinginkan.

Kriteria terakhir adalah kriteria bahan baku dengan subkriteria ukuran bahan baku dan kualitas. Ukuran bahan baku mencakup berat, jenis kertas, serta luas kertas. Satuan pesanan kertas biasanya berupa satuan berat (ton). Subkriteria kedua adalah kualitas. Kualitas sudah menjadi hal yang umum dan sangat penting dalam pemilihan produk. Untuk menjaga kualitas produk media cetak yang dihasilkan PT Solo Grafika Utama, kualitas bahan baku perlu diperhatikan. Supplier yang dapat memasok bahan baku dengan kualitas terbaik merupakan supplier yang patut dipilih. Karena,apabila spesifikasi kertas yang ada tidak sesuai dengan yang dibutuhkan, jumlah produk akhir yang dihasilkan bisa berkurang. Hal ini tentu sangat merugikan pihak perusahaan. Oleh sebab itu, pihak PT Solo Grafika Utama mengharapkan supplier yang dapat memenuhi pesanan sesuai dengan spesifikasi produk yang diinginkan.

Selain metode ANP terdapat metode pengambilan keputusan lain yaitu Analytic Hierarchy Process (AHP). Dibandingkan metode AHP, dengan menggunakan metode ANP dimungkinkan untuk melakukan pemodelan hubungan keterkaitan antar kriteria atau subkriteria dalam model pengambilan keputusan. Hubungan yang terjadi antar subkriteria didapatkan melalui cara yang sama dengan tahap identifikasi kriteria ataupun subkriteria. Hasil identifikasi tersebut menunjukkan adanya hubungan antar subkriteria yang dapat dibagi menjadi dua, yaitu inner dependence dan outer dependence.

Inner dependence adalah hubungan yang terjadi antar subkriteria di dalam kriteria yang sama, yaitu antara frekuensi pemenuhan pesanan dengan frekuensi ketepatan waktu pengiriman, potongan harga dengan harga, kepercayaan dengan cara pembayaran, serta kepercayaan dengan fleksibilitas. Kemampuan supplier memenuhi jumlah pesanan bahan baku yang diinginkan pembeli akan mempengaruhi ketepatan waktu pengiriman. Apabila supplier memiliki bahan baku yang cukup maka akan mudah bagi supplier untuk mengirimkan secara tepat waktu, namun apabila sebaliknya maka sulit untuk memenuhi kesepakatan waktu pengiriman yang telah ditetapkan. Potongan harga adalah subkriteria yang mempengaruhi harga bahan baku kertas. Adanya potongan harga akan membuat bahan baku kertas lebih murah. Subkriteria selanjutnya adalah kepercayaan. Kepercayaan yang telah dibangun memungkinkan supplier memberi alternatif cara pembayaran yang lebih mudah. Perlakuan supplier ini akan berbeda apabila dihadapkan dengan pembeli yang baru. Track record pembeli yang turut membangun 
kepercayaan ini. Hubungan selanjutnya adalah kepercayaan terhadap fleksibilitas. Sama halnya dengan cara pembayaran, hubungan baik yang telah terjalin antara pembeli dan supplier akan meningkatkan toleransi terhadap adanya perubahan pesanan bahan baku.

Jenis hubungan antarsubkriteria yang kedua dinamakan outer dependence. Hubungan ini terjadi antar subkriteria di kriteria-kriteria yang berbeda. Hubungan-hubungan ini antara lain frekuensi pemenuhan pesanan dengan ukuran bahan baku, harga, potongan harga, dan cara pembayaran, ukuran bahan baku dengan harga, kualitas dengan harga, dan kepercayaan dengan potongan harga. Seperti telah dijelaskan sebelumnya, frekuensi pemenuhan pesanan berkaitan dengan ketersediaan barang di pihak supplier. Ketersediaan barang akan mempengaruhi ukuran bahan baku yang dipasok ke pembeli. Ketersediaan bahan baku juga akan mempengaruhi harga dan potongan harga. Hubungan yang terjadi antara subkriteria-subkriteria ini sesuai dengan teori supply dan demand secara umum. Hubungan lainnya adalah dengan cara pembayaran. Ketersediaan bahan baku yang terlalu banyak di pihak supplier biasanya membuat supplier mempunyai inisiatif menawarkan cara pembayaran yang lebih mudah sebagai strategi pemasaran agar barang-barang yang dimilikinya cepat terjual. Hubungan selanjutnya adalah antara ukuran dan harga. Spesifikasi bahan baku yang berbeda tentunya memiliki harga yang berbeda pula. Hubungan antara kualitas dan harga adalah semakin tinggi kualitas bahan baku maka harga dari bahan baku tersebut akan semakin tinggi. Subkriteria lain yang berhubungan adalah kepercayaan dan potongan harga. Kepercayaan yang dalam hal ini adalah relasi yang baik dan telah terjalin lama memang memberikan banyak keuntungan bagi pembeli, salah satunya adalah kemungkinan diberikannya potongan harga dalam pembelian bahan baku. Semua hubungan outer dependence antar subkriteria ini secara otomatis menimbulkan hubungan antar kriteria dalam proses pengambilan keputusan. Seluruh kriteria, subkriteria, serta hubungan yang telah teridentifikasi pada akhirnya digunakan dalam pembangunan model pengambilan keputusan.

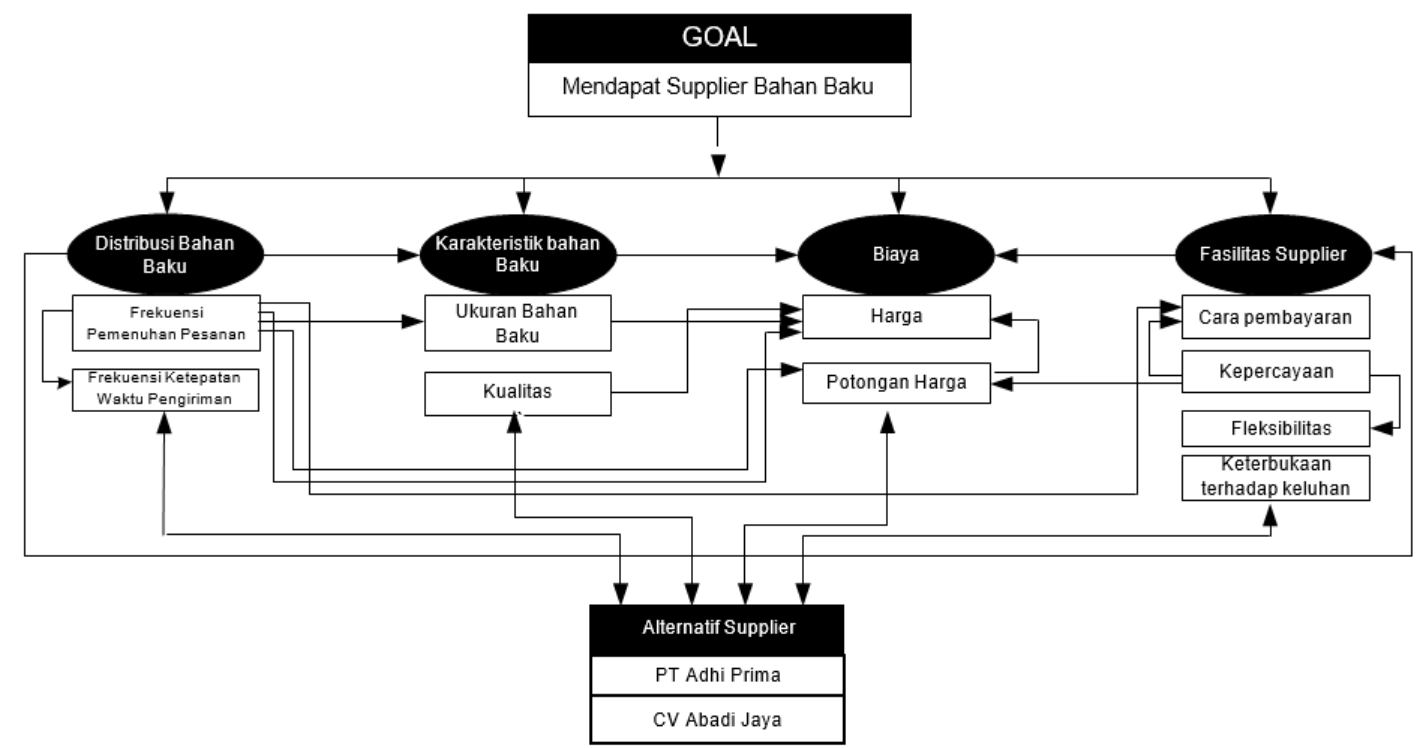

Gambar 2. Model Keterkaitan Analytic Network Process dalam Pemilihan Supplier Bahan Baku Kertas PT Solo Grafika Utama

Model yang telah dibangun akan digunakan untuk memilih kertas terbaik sebagai bahan baku. Tahap awal dalam rangkaian proses pemilihan supplier ini dengan cara melakukan perbandingan kepentingan antarkriteria dan subkriteria yang terdapat dalam model. Proses perbandingan ini dilakukan dengan tujuan mengetahui seberapa penting/baik suatu kriteria atau subkriteria dibandingkan kriteria/subkriteria lainnya dalam pencapaian suatu tujuan atau berdasarkan kriteria kontrol tertentu. Penilaian tingkat kepentingan dilakukan oleh kepala bidang umum di PT Solo Grafika Utama. Berdasarkan model keterkaitan yang telah dibangun, maka dilakukan 6 proses perbandingan antarkriteria dan 24 perbandingan antar subkriteria. 
Ketiga puluh perbandingan beserta kriteria/subkriteria kontrol masing-masing perbandingan dapat dilihat pada Tabel 1 .

Tabel 1. Perbandingan Kriteria dan Subkriteria

$$
\text { Perbandingan Antarkriteria }
$$

\begin{tabular}{|c|c|c|}
\hline No & Kriteria Kontrol & Kriteria yang dibandingkan \\
\hline 1 & Tujuan/Goal & Biaya, Distribusi Bahan Baku, Fasilitas Supplier, Karakteristik Bahan \\
\hline 2 & Distribusi Bahan Baku & $\begin{array}{l}\text { Alternatif Supplier, Biaya, Distribusi Bahan Baku, Fasilitas } \\
\text { Supplier, Karakteristik Bahan Baku }\end{array}$ \\
\hline 3 & Karakteristik Bahan & Alternatif Supplier, Biaya \\
\hline 4 & Biaya & Alternatif Supplier, Biaya \\
\hline 5 & Fasilitas Supplier & Alternatif Supplier, Biaya, Fasilitas Supplier \\
\hline 6 & Alternatif Supplier & Biaya, Distribusi Bahan Baku, Fasilitas Supplier, Karakteristik Bahan \\
\hline 7 & \multirow{4}{*}{$\begin{array}{l}\text { Mendapat Supplier } \\
\text { Kertas Terbaik }\end{array}$} & Frekuensi Ketepatan Waktu Pengiriman, Frekuensi Pemenuhan Pesanan \\
\hline 8 & & Kualitas, Ukuran Bahan Baku \\
\hline 9 & & Harga, Potongan Harga \\
\hline 10 & & Cara Pembayaran, Fleksibilitas, Kemungkinan Menerima Keluhan, \\
\hline 11 & \multirow{2}{*}{$\begin{array}{l}\text { Frekuensi } \\
\text { Pemenuhan } \\
\text { Pesanan }\end{array}$} & PT Adhi Prima, CV Abadi Jaya \\
\hline 12 & & Harga, Potongan Harga \\
\hline 13 & $\begin{array}{l}\text { Frekuensi } \\
\text { Ketepatan Waktu }\end{array}$ & PT Adhi Prima, CV Abadi Jaya \\
\hline 14 & Ketebalan Bahan & PT Adhi Prima, CV Abadi Jaya \\
\hline 15 & Kualitas & PT Adhi Prima, CV Abadi Jaya \\
\hline 16 & Harga & PT Adhi Prima, CV Abadi Jaya \\
\hline 17 & Potongan Harga & PT Adhi Prima, CV Abadi Jaya \\
\hline 18 & Cara Pembayaran & PT Adhi Prima, CV Abadi Jaya \\
\hline 19 & \multirow{2}{*}{ Kepercayaan } & PT Adhi Prima, CV Abadi Jaya \\
\hline 20 & & Cara Pembayaran, Fleksibilitas \\
\hline 21 & Fleksibilitas & PT Adhi Prima, CV Abadi Jaya \\
\hline 22 & $\begin{array}{c}\text { Keterbukaan } \\
\text { Terhadap } \\
\text { Keluhan }\end{array}$ & PT Adhi Prima, CV Abadi Jaya \\
\hline
\end{tabular}

\begin{tabular}{|c|c|c|}
\hline 23 & & Frekuensi Ketepatan Waktu Pengiriman, Frekuensi Pemenuhan Pesanan \\
\hline 24 & \multirow{3}{*}{ PT Adhi Prima } & Kualitas, Ukuran Bahan Baku \\
\hline 25 & & Harga, Potongan Harga \\
\hline 26 & & Cara Pembayaran, Fleksibilitas, Kemungkinan Menerima Keluhan, \\
\hline 27 & \multirow{4}{*}{ CV Abadi Jaya } & Frekuensi Ketepatan Waktu Pengiriman, Frekuensi Pemenuhan Pesanan \\
\hline 28 & & Kualitas, Ukuran Bahan Baku \\
\hline 29 & & Harga, Potongan Harga \\
\hline 30 & & Cara Pembayaran, Fleksibilitas, Kemungkinan Menerima Keluhan, \\
\hline
\end{tabular}

Penilaian tingkat kepentingan dilakukan dengan menggunakan kuesioner yang berisi perbandingan berpasangan antarkriteria maupun subkriteria. Adapun salah satu rekapitulasi hasil penilaian kepentingan yang telah dilakukan dapat dilihat pada Tabel 2. 
Tabel 2. Perbandingan dengan Kriteria Kontrol: Tujuan/Goal

\begin{tabular}{|c|c|c|c|c|}
\hline & Biaya & $\begin{array}{c}\text { Distribusi } \\
\text { Bahan Baku }\end{array}$ & $\begin{array}{l}\text { Fasilitas } \\
\text { Supplier }\end{array}$ & $\begin{array}{c}\text { Karakteristik } \\
\text { Bahan Baku }\end{array}$ \\
\hline Biaya & 1 & $1 / 5$ & $1 / 3$ & $1 / 2$ \\
\hline Distribusi Bahan Baku & 5 & 1 & 4 & 3 \\
\hline Fasilitas Supplier & 3 & $1 / 4$ & 1 & $1 / 3$ \\
\hline $\begin{array}{l}\text { Karakteristik Bahan } \\
\text { Baku }\end{array}$ & 2 & $1 / 3$ & 3 & 1 \\
\hline
\end{tabular}

Berdasarkan matriks perbandingan yang ditunjukkan Tabel 2, dapat disimpulkan bahwa fasilitas supplier dianggap 3 kali lebih penting dibandingkan dengan kriteria biaya dalam mencapai tujuan, distribusi bahan baku dianggap 3 kali lebih penting daripada karakteristik bahan baku, serta karakteristik bahan baku dianggap 2 kali lebih penting dibandingkan biaya. Hasil penilaian ini harus konsisten atau paling tidak memiliki inkonsistensi yang kecil. Namun pada kenyataannya, penilaian yang diberikan pada dua kriteria berbeda. Oleh sebab itu, untuk mendapatkan keputusan yang dapat diandalkan maka konsistensi dari proses penilaian harus terlebih dahulu diuji sehingga diharapkan nilai inkonsistensi mendekati nol. Batas nilai inkonsistensi yang digunakan dalam penelitian ini maksimal sebesar 0.1. Nilai inkonsistensi yang dihasilkan dari data penilaian pada Tabel 2 adalah sebesar 0.0899 sehingga dapat disimpulkan bahwa proses penilaian cukup konsisten.

Pengolahan data tahap selanjutnya yang terdiri dari perhitungan eigen value dari tiap perbandingan dan pembuatan limiting matrix. Proses pengolahan data penelitian, termasuk pengujian konsistensi dilakukan dengan bantuan perangkat lunak Super Decisions. Pada akhirnya diperoleh limiting matrix yang akan digunakan untuk memilih supplier kertas (bahan baku) terbaik. Rekapitulasi nilai limiting matrix dapat dilihat pada Tabel 3 di bawah ini.

Tabel 3. Prioritas Berdasarkan Limiting Matrix

\begin{tabular}{lc}
\hline \multicolumn{1}{c}{ Subkriteria } & Limiting \\
\hline CV Abadi Java & 0.14113 \\
\hline PT Adhi Prima & 0.27719 \\
\hline Harga & 0.15962 \\
\hline Potongan Harga & 0.05321 \\
\hline Frekuensi Ketepatan Waktu Pengiriman & 0.06057 \\
\hline Frekuensi Pemenuhan Pesanan & 0.05502 \\
\hline Cara Pembavaran & 0.03204 \\
\hline Fleksibilitas & 0.01852 \\
\hline Kepercavaan & 0.03853 \\
\hline Meterbukaan Terhadap Keluhan & 0.04860 \\
\hline Kualitas & 0 \\
\hline Ukuran Bahan Baku & 0.06111 \\
\hline
\end{tabular}

Pada tabel di atas dapat disimpulkan bahwa PT Adhi Prima merupakan supplier terbaik untuk bahan baku kertas. Hal ini dapat dilihat dari nilai limiting matrix pada kriteria alternatif supplier di 3 baris pertama di mana PT Adhi Prima mempunyai nilai yang lebih besar daripada CV Abadi Jaya. 


\section{Kesimpulan}

Dari penelitian ini dapat ditarik kesimpulan sebagai berikut bahwa penyebab keterlambatan pengadaan barang terdapat empat faktor yaitu manusia, mesin, metode, dan lingkungan. Sedangkan pengaruh dari keterlambatan pengadaan yaitu proses produksi terhambat atau ditunda, maka pengerjaan produk melebihi jadwal produksi yang telah ditetapkan di awal. Sehingga pengiriman produk ke konsumen mengalami keterlambatan dan konsumen tidak puas dengan kinerja perusahaan dan beralih ke perusahaan yang lain. Solusi untuk mengatasi masalah keterlambatan adalah dengan menerapkan metode ANP (Analytic Network Process). Proses pengambilan keputusan pemilihan supplier bahan baku kertas di PT. Solo Grafika Utama melibatkan kriteria biaya, kriteria distribusi bahan baku, kriteria fasilitas supplier dan kriteria karakteristik bahan baku. Supplier PT Adhi Prima terpilih sebagai supplier terbaik dengan mendapatkan nilai limiting matrix terbesar yaitu 0.27719.

Pada penelitian ini, supplier hanya pada PT. Adhi Prima dan CV. Abadi Jaya tanpa memerhatikan supplier lain yang berpotensi menjadi supplier untuk PT. Solo Grafika Utama dengan keunggulan-keunggulan yang dimiliki. Selain itu, penilaian pemilihan supplier hanya dibatasi pada empat kriteria tanpa memerhatikan aspek lain seperti lokasi dan lain-lain. Hasil model pengambilan keputusan yang digunakan juga terhitung model yang sudah lama muncul sehingga terdapat model yang lebih baru dan menghasilkan output yang lebih akurat. Sehingga pada penelitian selanjutnya sangat memungkinkan untuk memodifikasi model pengambilan keputusan yang telah dibangun dengan memasukkan lebih banyak kriteria lain sebagai bahan pertimbangan yang mungkin muncul seiring perkembangan kebutuhan dan keinginan konsumen yang semakin kompleks.

\section{Daftar Pustaka}

Goodwin, P. dan Wright, G. (2004). Decision Analysis for Management Judgment, Third Edition. London: John Wiley \& Sons.

Herjanto, E. (2009). Sains Manajemen : Analisis Kuantitatif Untuk Pengambilan Keputusan. Jakarta : Grasindo.

Lead Time. (2010). Diakses pada 1 Desember 2015, dari http://lindhasimanjuntak.blogspot.co.id/2010/12/lead-time.html

Mardiansyah dan Ikhwana, A. (2014). Perancangan dan Perbaikan Sistem Kerja Dalam Upaya Mengendalikan Kecacatan Pada Proses Pembuatan Nata De Coco (Studi Kasus di PD. Suci Segar Garut). Jurnal Kalibrasi Sekolah Tinggi Teknologi Garut.

Saaty, T.L. (1991). Pengambilan Keputusan Bagi Para Pemimpin. Jakarta : IPPM dan PT Pustaka Binaman Pressindo.

Saaty, T.L. (1996). Decision Making with Dependence And Feedback The Analytic Network Process. Pittsburgh: RWS Publications.

Saaty, T.L. (2004). The Analytic Network Process : Benefits Opportunities Cost and Risks Decision Example. Pittsburgh: RWS Publications.

Strategi Procurement. (2013). Diakses pada 1 Desember 2015, dari http://manajemenproduksi.com/strategi-pengadaan-dan-procurement-barang-yang-cerdas-danhemat-biaya/\#sthash.FA2prW5z.dpuf

Supranto, J. (2005). Teknik Pengambilan Keputusan. Jakarta: Rineka Cipta.

Sutedi, A. (2012). Aspek Hukum Pengadaan Barang \& Jasa dan Berbagai Permasalahannya. Edisi 2. Jakarta: Sinar Grafika.

Yulianti, M. (2013). Penerapan Metode Analytic Network Process (ANP) dan Technique For Order Preference By Similarity To Ideal Solution (TOPSIS) dalam Pemilihan Supplier. Diakses dari http://www.repository.upi.edu 